\title{
Bedřich Smetana's Physiognomic Appearance
}

\section{Emanuel Vlček}

\section{Introduction}

Bedriich Smetana has been discussed in numerous articles, written by musicologists and music historians, as well as memoirs of his contemporaries. The information on his physical appearance, however, is just fragmentary and subjective. His own complaints suggest that in the first half of his life, he suffered from health problems. The focal point of the second half of his life was the onset of deafness and fighting this unimaginable obstacle from the age of fifty. In the sixth decade of his life, his creative forces were at their peak, his broadly spread work musically original and purposefully patriotic - today's ordinary listener does not realise that Má vlast [My Fatherland] was written by a deaf composer. We owe to Smetana the foundation of typically Czech music, and, from the mid-19th century, the importance of its position in the European context.

For Smetana's loss of hearing, the musician's most valuable sense, there was no cure. The illness, irreversibly leading to his death, changed the artist's family and social life. He was unable to conduct, or to give concerts, but he did not submit to his fatal misfortune. As he wrote himself, he appealed to his spirit, which helped him to imagine the compositions, as if he would have been hearing them. Even in the last months of his life, in which his primary disease developed in a serious way, he tried to write the score of the opera Viola; on February 25th, 1884 , he wrote on one of the sheets of its fragment "fine" and "last sheet". He died on May 12th, 1884, in the Institute for Mentally Disturbed in Prague, of related pneumonia.

Bedřich Smetana's body was, after a ceremonial funeral, interred in a vault at the Vyšehrad cemetery in Prague. The vault was first re-arranged in 1911. Today, it is not possible to find, whether the composer's remains were left in their original coffin, or if they were transferred to a new one.

In 1983, Dr Miloslav Malý, Director of the Museum of Czech Music, a department of which the Bedřich Smetana Museum became in 1976, suggested 
to the the Czechoslovakian Minister of Culture, JUDr Milan Klusák, how the dismal state of the neighbourhood of Smetana's grave could be changed. The arrangement of the grave was to be made on the occasion of the Year of Czech Music 1984. Apart from the restoration of the vault, frequently flooded due to various land works damaging the cemetery's water table, treatment should also have been given to the composer's remains. After delays, the new director of the Museum of Czech Music, Dr Bohuslav Čížek, had to point out the unbearable situation again. He also newly opened the inquiry into Smetana's illness, by that time discussed abroad. The whole affair was dealt by in co-operation with the Head of the Bedřich Smetana Society, Dr Václav Holzknecht, and the representatives of Smetana's family. Agreed by the Ministry of Culture, the project started on November 12th, 1987. Smetana's heavily damaged remains had to be first appropriately treated in the laboratory, and the remaining time was to be used in the best way possible to research the characteristics of the composer's physical appearance, his deafness and state of health. Due to the technical problems, all this was possible only in November 1987. The treatment and research were limited by time, because the body was to be deposited in the restored vault on the occasion of the anniversary of the composer's death and opening of the 1988 Prague Spring Festival.

I asked for the co-operation the specialists who took part in the earlier research of the personalities of Bohemian history: the anatomist Prof. MUDr. R. Čihák (Institute of Anatomy of the Ist Faculty of Medicine of Charles University in Prague), the pathologist Prof. MUDr. P. Strejc (Institute of Forensic Medicine of the Ist Faculty of Medicine of Charles University in Prague), the otolaryngologist Prof. MUDr. K. Sedláček (Phoniatric Laboratory of the Ist Faculty of Medicine of Charles University in Prague), the stomatologists Doc. MUDr. J. Ramba and Doc. MUDr. J. Handzel (both of them from the Department of Paediatric Stomatology of the 2nd Faculty of Medicine of Charles University in Prague), and the chemist Dr. J. Musil (Laboratory of Flame Spectroscopy of the Institute of Chemical Technology in Prague). In 1894, Smetana's spectacles had been examined by the ophtalmologist Doc. MUDr. L. Cigánek (Department of Opthalmology of the Central Military Hospital in Prague), who also assessed his sight. In 1993, the researchers of Smetana's deafness were joined by the otolaryngologist MUDr. M. Valvoda (Department of Otorhinolaryngology of the Ist Faculty of Medicine of Charles University in Prague). The radiology documentation (including the Rank-Xerox X-Ray photographs and the CT scans) was provided by J. Brzorád (Department of Radiology of the Teaching Hospital in Prague-Vinohrady). Later, also other specialists took part in this research: the otolaryngologist Prof. MUDr. J. Betka (Department of Otorhinolaryngology of 
the Ist Faculty of Medicine of Charles University in Prague), the anthropologist Doc. RNDr. Z. Šmahel (Department of Plastic Surgery of the 3rd Faculty of Medicine of Charles University in Prague), the pathologist Prof. MUDr. C. Povýšil (Institute of Pathology of the Ist Faculty of Medicine of Charles University in Prague), the histologist RNDr. A. Němečková (Institute of Histology and Embryology of the Medical Faculty of the Medical Faculty in of the Charles University in Prague), the serologist MUDr. M. Knappová (National Reference Laboratory for Diagnostics of Syphillis in Prague) and the chemists Ing. J. Kučera and L. Soukal (both of the Institute of Nuclear Physics of the Academy of Science of the Czech Republic in Rež u Prahy). Their papers became an integral part of the book Bedřich Smetana, fyzická osobnost a bluchota [Bedřich Smetana, his Physiognomy and Deafness]. ${ }^{1}$

After the anthropological and medical examination was finished, Smetana's chemically conserved remains were, on May 2nd, 1988, presented to a specialist commission, who agreed with the preservation and research procedures. After that, the shrouded remains were put in a new lead casket, together with an identity document. The same day, the sealed casket was deposited in the renovated Smetana vault at the Vyšehrad Cemetery, and the grave was covered by its original lid.

\section{Researching Bedřich Smetana's Physiognomy}

Up to 1987, Smetana's physiognomy was known only from the memoirs of his contemporaries, diaries and official documents, influenced by guessing, inspiration and wishes - the direct medicinal morphological evidence testified only vaguely to his physiognomy. From the time of the composer's death, his deafness, health and cause of his death were discussed anew four times. At first, his state of health and the cause of death were stated, in a matter-of fact way, shortly after his death. Secondly, a lengthy discussion started around the one hundredth anniversary of Smetana's birth. Two rival propositions of the primary illness, leading to death, were suggested. The musicologist Dr. Vladimír Balthasar, neurologist prof. Ladislav Haškovec and psychiatrist Prof. Antonín Heveroch again discussed the autopsy findings of Prof. Jaroslav Hlava. None of their interpretations were based on new information. A decisive turn was brought at the meeting of the Society of Czech Physicists, on February 25th, 1925. Balthasar heavily criticised Heveroch's conclusions and diagnosis, pointing out discrepancies with the original diagnosis of the pathologist Hlava. Apart from the physicists, Prof. Josef

\footnotetext{
${ }^{1}$ Emanuel Vlček et al., Bedřich Smetana, fyzická osobnost a hluchota [Bedřich Smetana, his Physiognomy and Deafness] (Praha: Vesmír, 2001).
} 
Pelnář also appeared, and the musicologist Prof. Zdeněk Nejedlý, who defended the genius's right of privacy.

The information on intimate relations, health or illness is protected by medical science as secret. Such matters should be discussed by specialists on a professional level, and any hunting for sensation should be avoided. For the genius's own sake, the truth should not be hushed up, but told by a relevant specialist. Where and to whom the truth is to be revealed, is also of importance. In this case, Bedřich Smetana's primary disease, responsible for ending his time on earth, was to be specified. Such knowledge should help the proper appreciation of the importance of Smetana's suffering - his permanent deafness - not only from the point of view of medicine, but also of art and history.

The pathological anatomist Jaroslav Hlava, who performed the autopsy, marked in the protocol the changes, which according to him, suggested an organic disease of the central system - the brain - as "p.p." (p.p. = progressive paralysis), i.e. a prolonged progressive paralysis. ${ }^{2}$ The psychiatrist Heveroch on the other hand, negated this conclusion, and spoke about the clinical arteriosclerotic confusion. ${ }^{3}$ The general national esteem which Smetana enjoyed, led to the aims to obscure the subsequent effects of his illness, and, therefore, Heveroch reacted in a restrained manner, even if, as an experienced clinical physicist, he certainly understood the type and course of the illness, which at that time, was in no way unique. Even Smetana himself knew well, that April 12th, 1874, was fatal for him. He marked this fact, entering the date, in his calendar notes - each April 12 th became for him a reminder, even if, naturally, he did not link it with the onset of his deafness.

The pathologist Prof. Heřman Šikl entered the later discussion on this subject in a very clear way (1925). The term "p.p." (Bayle, 1), was researched only later. The basic aim of the psychiatrists was to divide clinically the psychosomatic syndrome "p.p." from other advanced age dementias. The pathogenesis of the individual "p.p.", caused by a specific infection, was not known, up to the time when Nissl (1904) defined the pathologically-anatomical "p.p." characteristics and their relation to syphilis. His ideas were proven by the serological Wassermann reaction, finding the spirochetas in the brain tissue itself (Nogucki, 1913) and the macroscopic proof of the presence of ferrous pigment in the grey matter of the brain (Spatz, 1922). For these reasons, not even the second discussion could have led to a clear conclusion.

Thirdly, Smetana's primary illness and cause of death was questioned in the early 1960s, when they were dealt with by a foreign scholar, the otholaryngologist

${ }^{2}$ J. Hlava, “Zpráva o pitvě Bedřicha Smetany”, $\check{C} L \check{C}$ [Český lékařský časopis], no. 23 (1884): 323-324.

${ }^{3}$ A. Heveroch, "O chorobě mistra Bedřicha Smetany”, $\check{C} L \check{C}$, no. 20 (1924/63): 761-765. 
Dr. Med. H. Feldmann from Heidelberg, who looked into the historic sources. The possibility to research the private diaries, up to now deposited in safes, obtained for him from the then director of the Smetana Museum, Dr Miloslav Malý, the otholaryngologist Antonín Přecechtěl, member of the Czechoslovakian Academy of Sciences, supported by influential political functionaries.

Feldmann published his findings in 1964'; he stated that Smetana's deafness was caused by syphilitic infection. This conclusion, indeed, opened further discussion, based again on already known sources - nothing else was available. The luetic infection as a cause of deafness was rejected mainly by the otolaryngologists D. Boř́k and Boř́ková (1987), ${ }^{5}$ and the stomatologist J. Ramba (2000), who tried to replace this idea by new explanations and combined the already known facts.

Fourthly, the research was renewed due to the 100th anniversary of the composer's death, and the renovation of Smetana's vault. Only on this occasion, new information finished the not always dignified constructions, without speculative sensations being involved. Now there were the bodily remains, offering a possibility of objective findings.

\section{The State of Preservation of the Remains and Their Anthropological and Medical Examination}

Smetana's mummy was almost destroyed by repeated flooding of the grave - soft tissues turned into a black, messy matter. From the skeleton, covered by remnants of mummified tissues, survived a well-preserved skull and the long bones of the limbs. From the thorax survived the spinal column and scattered pelvic bones. The decomposed fragments of ribs, as well as the bones of the legs, covered by shoes and clothes, were totally demineralised. The bones of both hands, still strengthened by remnants of joint cases and ligaments, survived well. The crossed hands were lying on the chest, and, because they were not covered by clothes, they were not systematically humidified. The front of the thorax was the most decomposed, which, for the sake of mummification, was opened by the usual central cut. The stitching of the thoracic cavity, partly filled by herbs, had loosened in time, and the front of the chest sunk in. We did not find the body of the sternum, which had disintegrated, but just half of the manubrium sterni, due to the bilateral bone joint of the sternum and first pair of ribs, which has survived until today. Unexpectedly, in the messy mixture of mummified tissues, hyoid bone survived and a substantial part of the ossified thyroid cartilage.

\footnotetext{
${ }^{4}$ H. Feldmann, "Die Krankheit Friedrich Smetanas in otologischer Sicht auf Grund neuer Quellenstudien”, Monatsschrift für Ohrenheilkunde und Laryngo-Rbinologie 98, Heft 5 (1964): 209-226 (the English version was published in: The Music Review 32 (1971): 233-247).

${ }^{5}$ See bibliography in Vlček, Bedřich Smetana, 91.
} 
The right side of the mummy was leaning against the side of the coffin - while being interred in a narrow grave, the body had probably slid down; this contact caused disintegration processes of the right side of the body. Also damaged were the right side of the skull, right upper limb, right ilium of the pelvis, right femur, and, most of all, the bottom half of the right tibia. Because the remains of the tissues (skin, subcutaneous tissues and muscles) were much decomposed, we had to clean the skeleton of them, and, in this way, prevent further damage. After the bones were fully dried, we performed the usual reversible conservation of each bone by polyvinylacetate. Due to the treatment, the bones became dark brown, apart from the places where the compact surface was damaged, and the colour became ochre to whitish. The remains of the mummified soft tissues were dark brown to black, mostly of tar-like character.

It is interesting, that in such an unfavourable environment, most of the hair and beard had survived, and even the dense hair cover of the body, on the remains of the skin. The dark chestnut head of hair, with only few white patches, and a prominent white strip to the right from the centre, two to three centimetres broad, was brushed back. The light chestnut beard had more white patches, mainly on the sides of both halves of the bottom jaw. The body hair was also chestnut, with white patches.

\section{Conclusion of the Anthropological and Medical Research of Bedřich Smetana's Remains}

The results of several years team research brought a new, fundamental, and indisputable outlook on the composer's physiognomy, his deafness and the primary mortal illness. These findings complemented the knowledge, up to now based only on the composer's rich correspondence with friends as well as offices, and also on the period medical knowledge, documented by literature. Our work was interdisciplinary: we used literary documents, but compared them mainly with the primary biological sources - Smetana's bodily remains. To keep to the historical continuity, we incorporated in our text all known conclusive literary historical data.

The whole of the anthropological and medical examination concentrated on three main aims: finding out about the physical characteristics of an individual, the onset and course of deafness in the frame of the state of health, and the clear specification of the primary illness from which Bedřich Smetana died. 


\section{Smetana's Physical Appearance}

There are numerous testimonies from reliable people, the idea of his appearance is complemented by many photographs. The following sums up what it is possible to discover from his remains:

1. Smetana was of medium height (164-166 centimetres), his body was slight and slender, his skeleton is proportionally perfectly symmetrical. Only the brachial index shows slightly shorter forearms. Smetana's hands were small, slender and almost feminine in structure.

2. Judging from the skull measurements, the head was short, high and of medium width, the brain cavity was 1286 cubic centimetres; the skeleton of the facial bones was high, with high eye-sockets, the nasal aperture was very small and the nose bones prominent.

3. The graphic reconstruction of the nose, based on the surviving bones, showed that it was strongly built, fleshy and dominating the face.

4. The heavy mane of hair and the full beard and whiskers were the finishing touches, typical for the characteristics of Smetana's face. Their arrangement, despite the period excesses, mainly in his youth, remained the same (the same applies for the shape of the eyebrows) and complements reliably Smetana's iconography. The "Smetanian", or better, "Lisztian" fashion.

5. The pigmentation complex was dark, the hair and beard black-brown, T-W according to the tables (Fischer-Saller and Schulz); the only existing information on Smetana's blue eyes was recorded by L. K. Žižka. ${ }^{6}$

6. The heavy mane of hair, ("Smetanian", or "Lisztian"), added to the feeling of a large head on a shorter neck. The shortness of the neck is documented by the grown-together second and third neck-spine vertebra, slightly influencing the holding and mobility of the head.

7. The contemporaries registered the conspicuous greasiness of Smetana's hair, linked to the higher activity of sebum glands, which, because Smetana's body hair was dense, often caused inflammation of the hair follicles and appearance of boils. The greasiness was natural, but it damaged the collars of Smetana's clothes. This is why he used to wash his dense hair each day and combed it for a long time.

8. A prominent feature of Smetana's face was his spectacles. He wore them from 1838 . He was strongly short sighted, and used bi-concave lenses $-7,0$ a -5,0 D. In his spectacles, no. 1, so-called lunettes, are bi-concave lenses $-7,0 \mathrm{D}$ (the arms were later repaired); the no. 2 spectacles have lenses 2

\footnotetext{
${ }^{6}$ See Vlček, Bedřich Smetana, 85.
} 
$-5,0 \mathrm{D}$ (the spectacles were bought after 1871 from the firm J. u. H. Sebek Mechaniker u. Optiker, Praha- Prag, Řetězová Street no. 7)

9. Unfortunately there is no recording of Smetana's voice. The literary documents mention a sonorous, soft baritone, with hardly noticeable nasal aspiration and strongly rolled " $r$ ". The unexpectedly strong voice was linked to his deafness and the structure of the heavy, fleshy nose built over the adequate nasal aperture in the facial part of the skull.

10. The skull gives several important pieces of information. On the right forehead protuberation is a well-healed scar. It could have been caused be the wound from June 17th, 1877 (falling from a chair and hitting his head on the corner of the table).

11. Of much greater importance is the asymmetry of the face skeleton. The right half of mainly the middle and bottom part is diminished. This was caused by a childhood wound, and the following osteomyelitis. As recorded by Josef Srb-Debrnov, (1880), at the age of eleven, Smetana took part in boy's game, during which a bottle of gun powder exploded, and a glass splinter damaged his face. The bleeding wound was treated by pond water and the following infection affected not only the soft face tissues, but also the bones. The wound healed well, but the bone inflammation became chronic, which, by a developing organism, lead to slowing-down of growth, and, due to that, diminishing of the affected part of the face. Such asymmetry of the face skeleton we also found in the Bohemian King, Jiří of Poděbrady, the Hussite leader Jan Žižka of Trocnov, and the Romantic poet Karel Hynek Mácha. ${ }^{7}$ The X-Ray photographs showed hypoplasy of the right middle and bottom third of the face skeleton. This clearly was not an acquired, but an inherent anomaly, also documented by the sclerotic changes of both right pars squamosa and pars petrosa of the temporal bone, the lamelar periostose of the mandible branch of the right jaw angle, where the border between the cortical and trabecular bone is not everywhere fully clear and the trabecular bone of the right half of the mandible, mainly of the ramus, is conspicuously marbled.

The X-Ray of the right temple bone was complemented by the CT examination, which showed that the airy and fine contour of the antrum, and the periantral pneumatisation of the antrum, exclude the possibility of a serious chronic inflammation of processus mastoideus.

${ }^{7}$ See, bibliography in Vlček, Bedřich Smetana, 91, cf. Vlček, "Karel Hynek Mácha”, Vesmír 66, no. 5 (1987): 253-257, no. 6 (1987): 318-325; Jak zemreli (Praha: Academia, 1993); Čestí králové (Praha: Vesmír, 2000). 
12. From Smetana's correspondence we know that he suffered from persistent tooth ache throughout his life. This is reliably documented by his incomplete and badly preserved dentition: he lost ten teeth, there are large parodontic changes, considerable resorption of alveolar extremities, a number of dental cavities and gangrenous teeth, and a metal filling. Smetana mentioned that he bought guttapercha, by which he filled his teeth. Guttapercha was used as a dental cavity filling; Smetana also used some sort of mouth-wash.

13. Findings on the bones of both hands are interesting. Due to the good state of preservation, we were able to measure both of the composer's hands, and assess them from the point of view of morphology. The hand bones were only scantily covered by remains of the mummified skin and subcutaneous tissues. The size of the hand bones suggest a really small hand; Smetana therefore certainly performed finger stretching exercises. Some pianists even used to stretch their fingers apart by pieces of wood. About Smetana, nothing like this is known; but it is sure that the training and effort to stretch marked in a specific way the palm side of his fifth metacarpal bone. On the palm side of both of the fifth metacarpal bones, developed a bone growth, one millimeter high and broad, and fifteen and seventeen millimeters long, created by long-time exercises of the palm muscles - musculus interosseus palmaris III, and musculus opponens digiti minimi. They witness the composer's effort to enlarge the finger extension, which, with his small hands, was important for covering the largest possible span of the keyboard. This finding shows that the deliberate stretching of the fingers strengthened the body mass of the musculus opponens minimi and supported the speedy movements of the musculus interosseus palmaris III. What type of chiroplast Smetana used, remains a question.

14. The innate ancylosis part of the neck spine (C2 and C3) and creation of a firm sternocostal arch in the thorax (ossification of the sternocostal cartillages of the first ribs) might explain the composer's problems while conducting and the recorded angle of his head.

15. The ABO serology. Four samples were tested by the method of absorption and elusion to find the group characteristics in the blood ABO system. Samples of mummified tissues and bones were pulverised, and absorbed by the anti-A or anti-B serum. After a rinse and elusion, blood- corpuscles belonging to the A or B group were added. Repeatedly, the corpuscles of both groups clustered. By repeated examination of the samples, no added blood-corpuscles produced the clusters. From these findings, we guess that Bedřich Smetana might have belonged to blood group O. Aglutination of 
the blood-corpuscles, added to the matter washed-out from the mummified tissues and bones could be non-specific.

\section{Composer’s Deafness}

The second group of questions dealt with the postlingual deafness.

1. Reconstruction of important parts of Smetena's clinical picture explicitly showed that the decisive moment was the second stage of syphilitic damage of the inner ear, transmitted by blood.

2. Of great help was the examination of the inner ear cavity directly in the skull, and taking out the auditory ossicles. The inflammatory damage of malleus and incus might have not been linked to the process leading to complete deafness. The osteomyelitis, which affected part of the right side auricular organ, was linked to the chronic, childhood otitises, not completely cured.

3. The venereal infection origin of the central deafness is explicitly documented by the positive serological test of Treponema pallidum. Usage of mercury, the period syphilis remedy, is documented by its extremely high content in the composer's bones and mummified tissues. Smetana's deafness is dealt with in detail by the following collective paper of the otolaryngologist J. Betka and other authors.

\section{The Primary Disease}

The third group of questions concerned the primary disease leading to premature death.

1. The finding of the pathologist, consulting with the physicists, has already been given during the epicrisis of the autopsy, as a "p.p.- a long lasting progressive paralysis". Even if the relationship between syphilis and the development of deafness was not yet known, and even if there is no record of reaction of the eye pupils, and no serological analysis or immediate histological examination of the brain tissues was performed, many period physicists clearly linked the clinical "p.p." symptoms with the, at that time, frequent syphilis. It could be felt from their attitude towards Bedřich Smetana's venereal disease, at that time a disapproved of disease, and their aims to protect such an important personality. To leave the telling and assessing of the real truth in the hands of specialists is supported also by the ways in which the whole case was treated by foreign specialists. The medical ethics should set an example, so that the right of protection of the genius's privacy could not be misused. The development of the disease was 
already realistically described by V. Balthasar in 1924, in his paper dealing with Smetana's personality and work from the point of view of psychology and psychopathology.

2. Serological proof of the syphilis diagnosis. M. Knappová, from the National Reference Laboratory for Syphilis Diagnosis in Prague, tested samples taken from the eye-socket, nose cavity, face of the skeleton, mummified soft tissues, contents of the brain cavity, and the left and right part of the pelvis. We focused on the possibility of the existence of the third stage of syphilis (eye-socket, nose cavity, parts of the skeleton), also looking for density of veins (contents of the brain cavity, left and right part of the pelvis, soft tissues). To extract the albuminous fraction, due to the small amount of material, only a one-hundred milligram sample from the eye-socket and nose cavity, and five-hundred milligram sample of other tissues was used. The extracts were tested for the specific Treponema pallidum antigens, and their modifications.

3. The TPHA examination of the basic sample, taken from the brain cavity tissues, face skeleton, right pelvis and the soft tissues, diluted in various ways, was positive. The FTA-ABS IgG test was borderline, only in the case of the soft tissues. The most convincing results were offered by the modern Rapid test Syphilis, produced by Omega, which is based on the recombinant Treponema antigens, and was positive in all cases. In this way, a positive reaction to the Treponema pallidum antigens was convincingly proven by no less than two independent reaction methods.

4. Level of mercury. Smetana was cured by mercury based remedies, mainly ointments (put on by spatula), and, therefore, a large amount of mercury was found in his bones and the remains of mummified tissues. This non-specific way was used while curing syphilis. The mercury content was checked by: Nuclear absorption spectrometry (J. Musil). Helped by the Czechoslovakian Instrument Trace Mercury Analyser TMA 84,-the level of mercury from $0,05-0,7 \%$, i.e. from $500-7000 \mu \mathrm{g} / \mathrm{g}$ was found in various samples. This variability does not allow for simple medium levelling.

Neutron activation analysis (J. Kučera, L. Soukal). The neutron activation analysis (NAA) is a nuclear analytic method, based on the radiation of the sample by neutrons, and measuring of the induced radioactivity, in general the gamma radiation. By radiation from a strong source of neutrons, such as the nuclear reactor, the NAA offers the possibility of stating very low levels of concentration of elements, or analysis of very small samples. The analysis is non-destructive, not involving chemical operations, only radiation by neutrons and spectroscopic measuring of the gamma radiation. This 
method is called instrumental (INAA). By the destructive method, suppressing the interfering elements offers a lower level of detection than INAA. The chemical operations follow the radiation of the sample, the method, therefore, is called radio-chemical (RNAA). The advantage of both NAA variants is the practically impossible blind experiment error, because what is measured, is the created radioactivity, not the chemical qualities of the elements. The method is much more accurate than other types of analysis, and, therefore, both of its variants were used to find the level of mercury content in Smetana's shin bone. Three parts of the bone were analysed, in which different levels of mercury concentration were expected. The accuracy of the proof was important; therefore, together with the bone samples, three control samples were also analysed, where the mercury content was known (standard reference material of the American National Institute of Standards and Technology - NIST SRM - 1515 Apple Leaves).

If compared with the levels given by Iyengar ${ }^{8}$ in his survey $(0,45 \mu \mathrm{g} / \mathrm{g})$, the concentration of mercury in Smetana's bones is very high. The extreme level of mercury in his bones and mummified tissues, again documents the usage of large amounts of mercury during the therapy. For completeness sake, levels of all elements in Smetana's shin bone were stated.

5. Apart from the primary disease, the autopsy showed developed arteriosclerosis of the arteries, mainly the aorta; brain atrophy, mainly the grey matter; and general atrophy of the body.

6. The direct cause of death was hepatisation of lung tissue by pneumonia.

7. One has to ask whether the primary venereal disease influenced Bedrich Smetana's creativity in the last decade of his life, when he also lost his hearing. Without any doubt, the influence was strong. It is known that by this disease, the hyperaemic brain membranes irritate the grey brain cortex and escalate its performance. This irritation could last up to the time when the deadly injurious matter takes over, and starts to destroy its bearer physically, and, over all, psychically.

In the last ten years of his life, starting from 1874, Smetana, already completely deaf, wrote half of his operas and finished the cycle of symphonic poems Má vlast [My Fatherland]. It is necessary to note, that from 1874, he composed only while following his inner hearing, similarly to Beethoven. On November 18th, 1874, he finished Vyšehrad, and, as in a trance, in the course of eighteen days, he added the poem Vltava [The Moldau]. He wrote in one sweep, and produced a fair manuscript, without drafts and mistakes.

${ }^{8}$ G. V. Iyengar et al, The Elemental Composition of Human Tissues and Body Fluids (Weinheim; New York: Verlag Chemie, 1978). 
The scores of his eight operas cover one thousand nine hundred pages of music, orchestral compositions one thousand one hundred; he also left about seven hundred and fifty piano, chamber and vocal works.

The same positively irritating influence of this bad infection is known in other personalities, such as Emperor Rudolf II, or Albrecht of Waldstein. Fighting the infection was sometimes short, sometimes long. For Smetana, it took ten years. A large role was played here by his personal will to contribute, by his Czech music, to the revival of his beloved nation. Up to his last moments, Smetana was responsible for his artistic output. In this wasting away person, higher psychic abilities took over. He wrote his last works, desperately fighting the illness and, by his final works, he was ahead of his time.

\section{The End of Life - and Its Incurable Cause}

The primary illness, which ended the composer's life, has been dealt with by many scholars. The most complex clinical picture of his last ten years was given by Prof. L. Haškovec (1925), who, in sixty-four pages, summed up all the substantial points of the discussion between the pathologist Hlava, neurologist Haškovec, psychiatrist Heveroch and writer Balthasar.

We know today, that Smetana's primary illness was caused by syphilis, the development and progression of which was model-like, with progressive paralysis in the third stage. Results of modern serological tests unanimously prove that he suffered from this disease, and the same applies to the then used mercury ointment therapy. A difficult question, today impossible to answer, was the exact time, and the person, who infected Smetana with venereal disease. Already Mirko Očadlík ${ }^{9}$, and most recently also Jaroslav Smolka ${ }^{10}$ pointed out the mid-1871 year, when the infection might have been first transferred. In Smetana's diary, from June17th, 1871 - April 29th, 1972, appear notes concerning symptoms of the illness: bladder inflammation, lymfadenitis of the lower abdomen and fork, accompanied by boils, generally described as ulcers. ${ }^{11}$ No link of these, either with an unnamed female member of the opera chorus (F. Pivoda's unpublished memoirs; Z. Mahler, 198912), or transfer of the inherited syphilis of the opera singer Lella Ricci ( $†$ 7. 8. 1871) could be objectively proven. ${ }^{13}$ A more provable

\footnotetext{
${ }^{9}$ Mirko Očadlík, Tvưrce české národní hudby Bedřich Smetana (Praha: Práce, 1945, 1949).

${ }^{10}$ Jaroslav Smolka, Osudové lásky Bedřicha Smetany (Praha: Media Bohemica, 1998), 63-67.

${ }^{11}$ J. Thomayer, Ze zápiski lékaře (Praha: Avicenum, 1977), 342-343.

${ }^{12}$ Zdeněk Mahler, Nekamenujte proroky. Kapitoly ze života Bedřicha Smetany (Praha: Albatros, 1989), 221.

${ }^{13}$ Smolka, Osudové lásky, 77-94.
} 
infection, from spring 1874, noted by Smetana himself, is not possible to attribute to any specific woman. Smetana's diaries, beginning from March 1874, show clearly the first stages of the development of syphilis, as well as the parallel onset of hearing problems, which, in October of the same year, resulted in his definitive loss of hearing. The 1874 infection might have been superimposed over the 1871 infection, but it is not possible to prove it. It is only possible to reconstruct the composer's clinical picture of this period of his life from his diaries, to document a ten year lasting development of this destructive illness, and to prove the diagnosis of the primary venereal disease which ended his life. Smetana, naturally, did not know that his deafness was caused by his illness, but his doctors must have had a clear idea of the progressing disease and its incurability.

Smetana himself linked his family, artistic and social limitations with the onset of deafness, which, according to him, started in June 1874 (letter to Dr. A. Č́žzek, Deputy Head of the Board of the Royal Land Czech Theatre, September 9th, 1874).

The deaf Smetana fought his immense handicap bravely and persistently. On June 11th, 1881, Prague's National Theatre opened with his opera Libuše, which he, however, did not conduct. He conducted only its overture on St Wenceslas Day, at the benefit concert on behalf of the burnt-down theatre. On this occasion, he complained to the orchestra: "It was, indeed, my wish to open the National Theatre and see Libuše, but my fate prevented it."
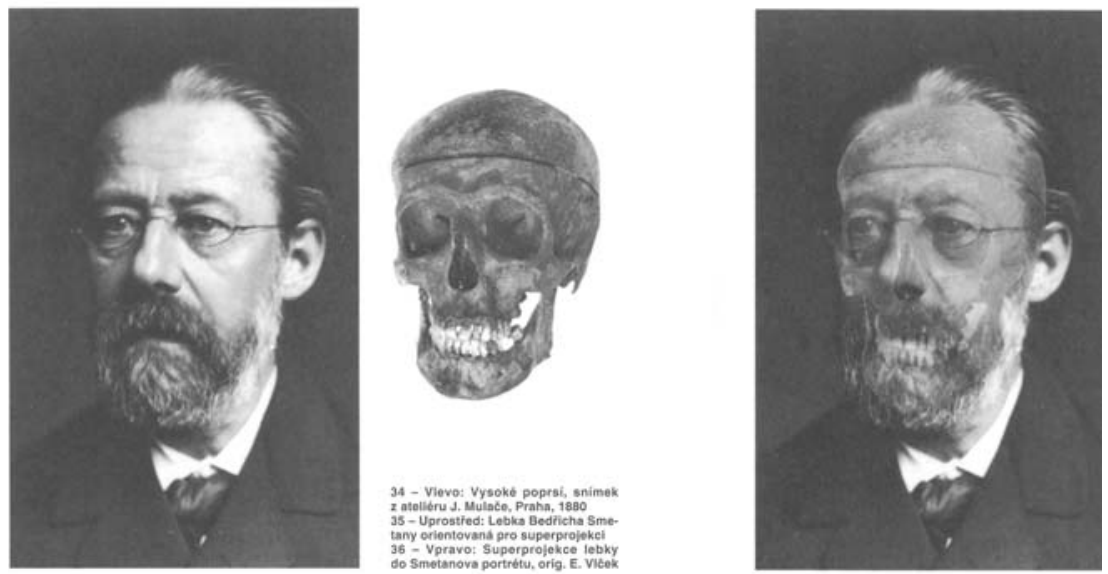

Picture 1: Certificate of authenticity of the remains. On the left: a bust, a photograph from the studio of J. Mulač, Praha, 1880. In the middle: the skull of B. Smetana positioned for superimposition. On the right: superimposition of Smetana's skull into his portrait. 

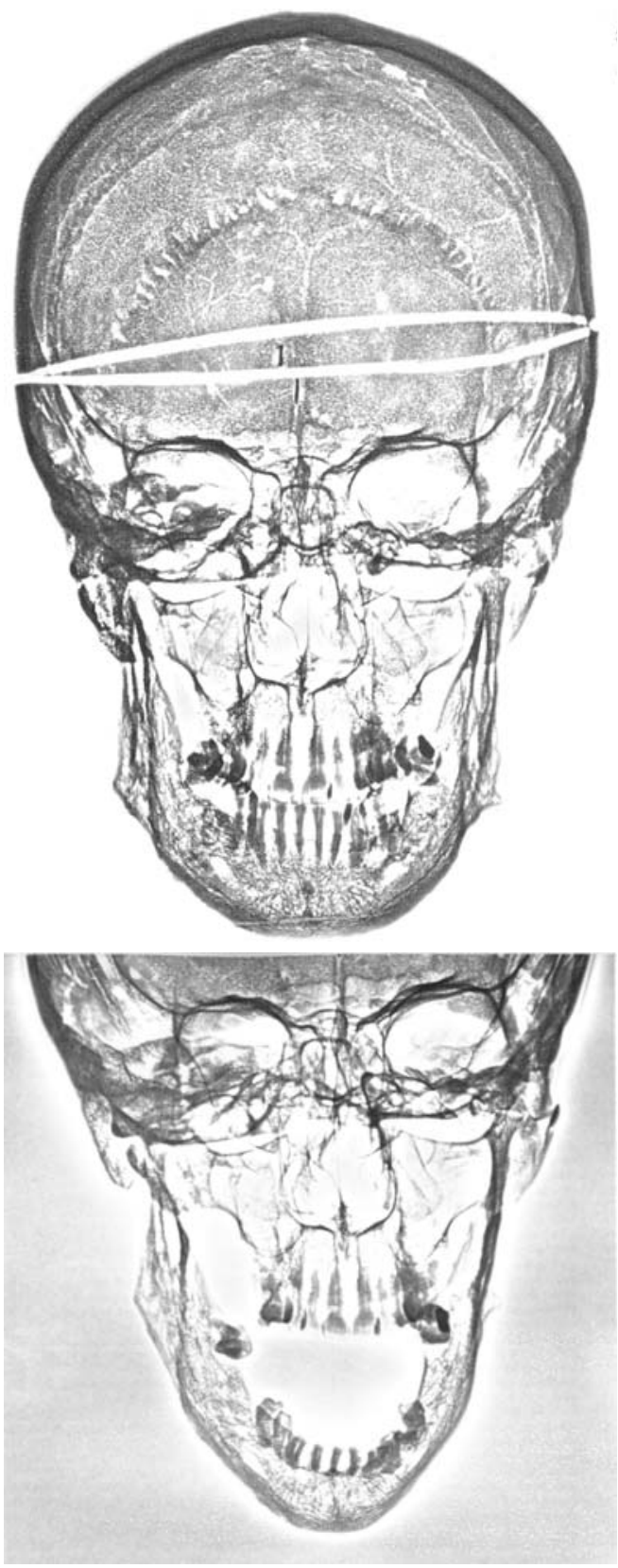

Picture 2: A radiograph of the skull in the sagittal superimposition.
Picture 3: The asymmetry of the skull in the sagittal orientation with an open mouth. 

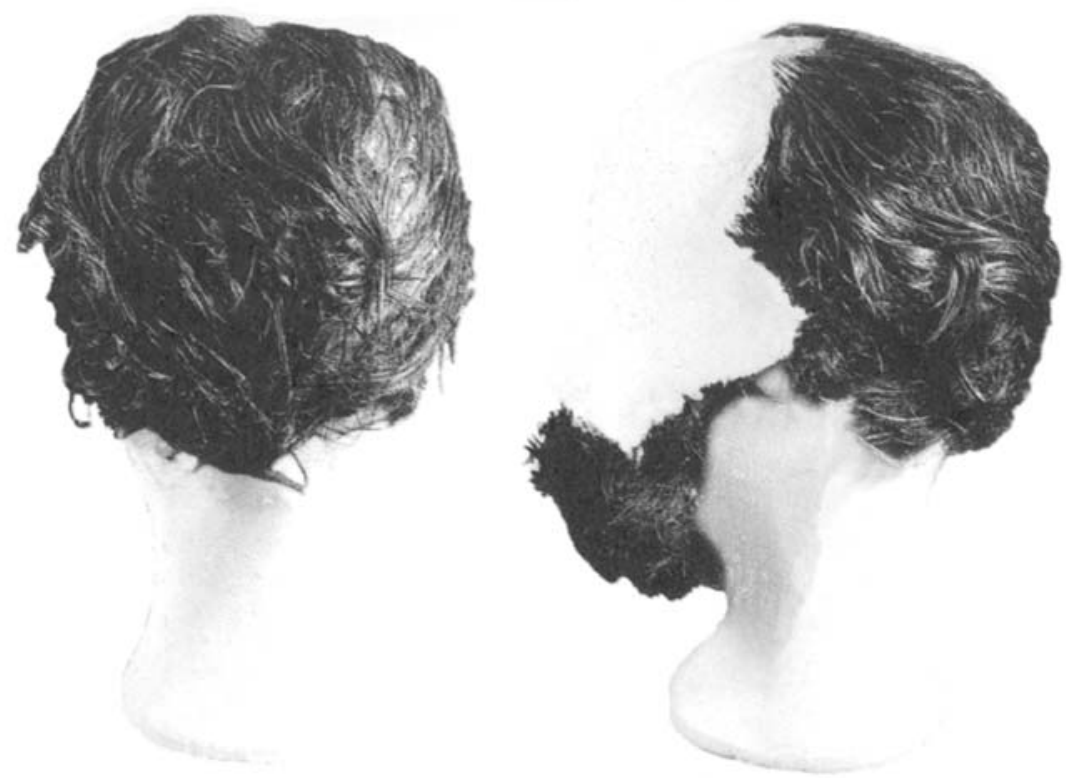

Picture 4: Preserved remains of B. Smetana's hair and beard.
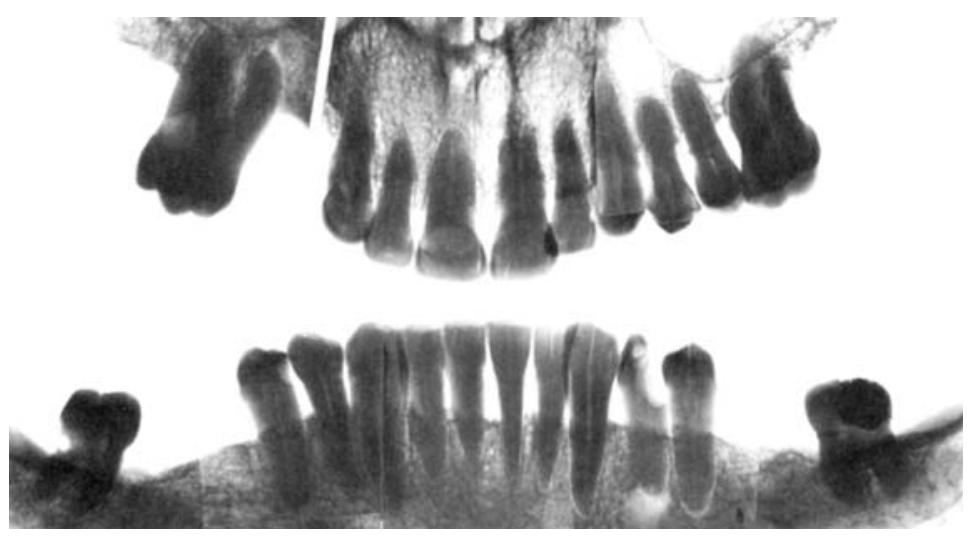

Picture 5: A radiograph showing the preservation of teeth. 

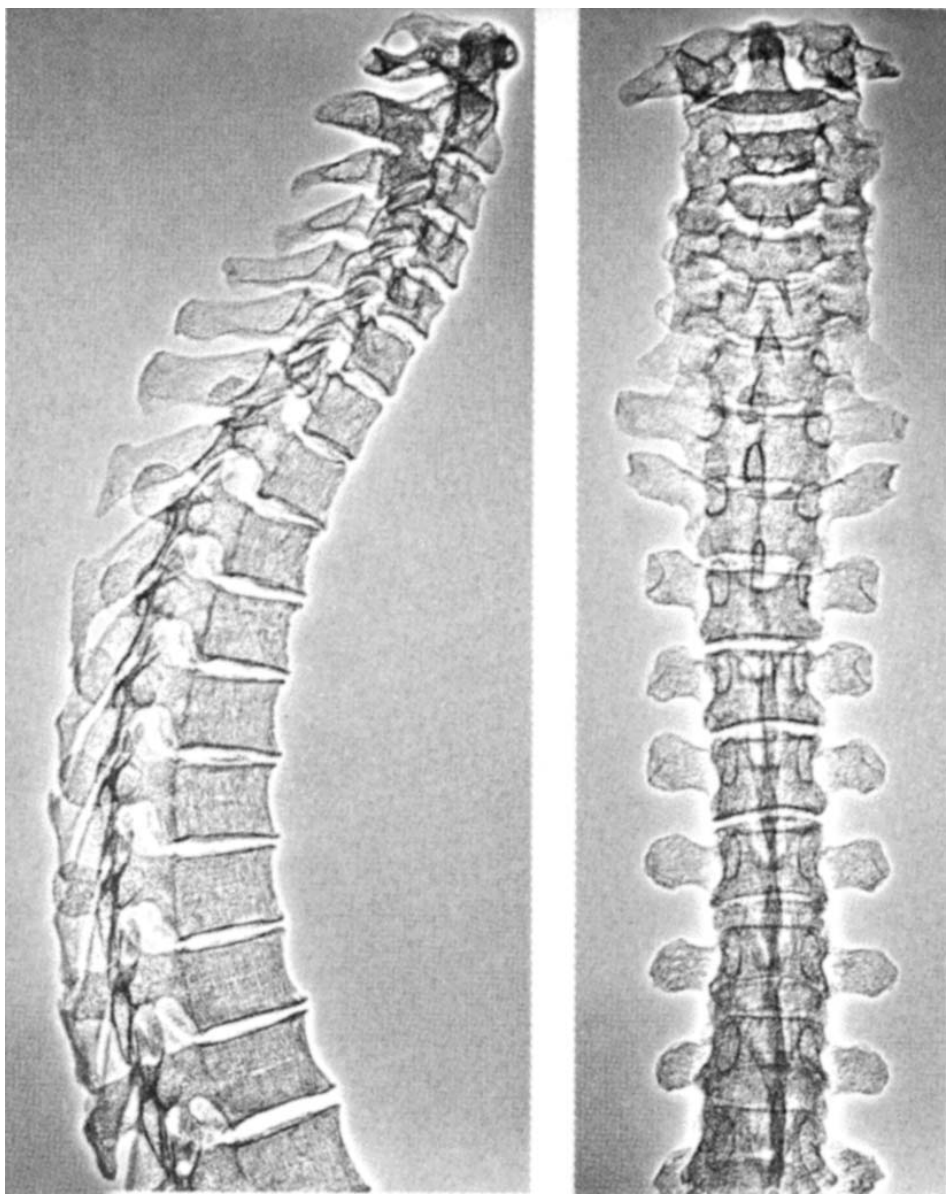

Picture 6: A radiograph of part of the spine in lateral and sagittal superimposition. 

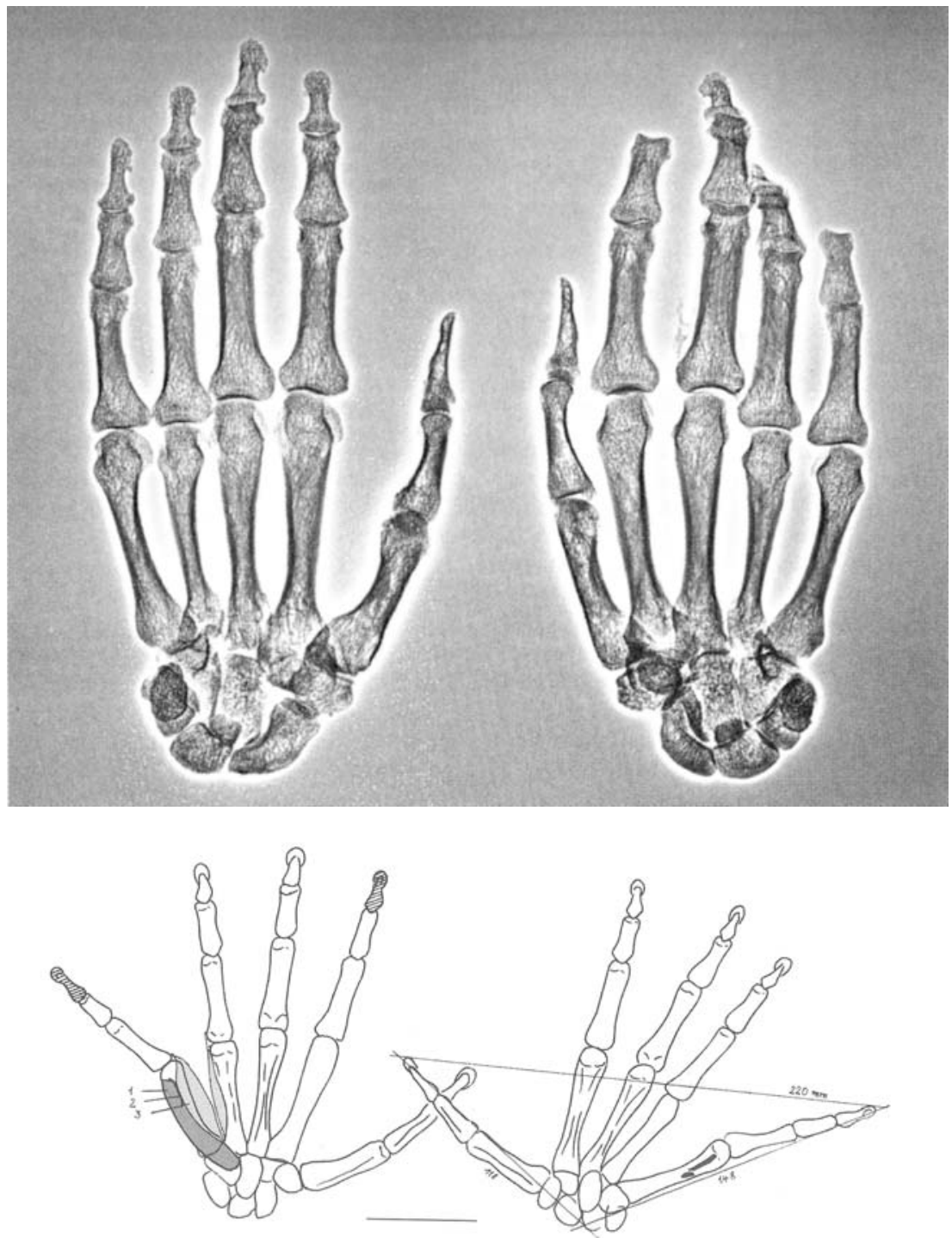

Picture 7: Radiographs of the skeleton of the hands. A scheme of the position and size of the stretched fingers of both hands. Bone crests (2) caused by hypertrophy of muscles at the fifth metacarpus $(1,3)$ are marked on the right hand. A maximum span of fingers, amounting to $220 \mathrm{~mm}$, is marked on the left hand. 


\section{Bedřich Smetana's Physiognomic Appearance}

\section{Abstract}

The reconstruction of Smetana's grave and exhumation of the virtuoso's remains in 1987 promoted research on Smetana's physical appearance. A relatively large team of experts in various fields of medicine (anatomy, pathology, phoniatrics, dentistry, etc.) was established. The results of the research were compared to contemporary visual materials and written documents (especially Smetana's diary records), including the memories of Smetana's friends. The results are divided into sections concerning the individual features, for instance facial asymmetry, myopia, pigmentation and diseases.

\section{Fyziognomie Bedřicha Smetany}

\section{Abstrakt}

Oprava Smetanova hrobu a vyzvednutí mistrových ostatků roku 1987 dalo impulz k výzkumu o Smetanově fyzické osobnosti. Byl sestaven poměrně rozsáhlý tým odborníků různých medicínských oborů (anatomie, patologie, foniatrie, stomatologie atd.). Výsledky zkoumání byly srovnány s dobovými obrazovými materiály i slovesnými dokumenty (zejména Smetanovými deníkovými záznamy), včetně vzpomínek Smetanových prátel. Výsledky jsou prezentovány formou jednotlivých bodů, napr. asymetrie obličeje, krátkozrakost, pigmentace, nemoci.

\section{Keywords}

Bedřich Smetana; physical appearance; physiognomy; examination of the body remains

\section{Klíčová slova}

Bedřich Smetana; fyzický vzhled; fyziognomie; výzkum tělesných ostatků 